\title{
Artigos
}

\author{
Breno Cypriano \\ Universidade Federal de Minas Gerais
}

\section{Construções do pensamento feminista latino-americano}

\begin{abstract}
Resumo: Discutir sobre um projeto teórico feminista a partir da América Latina requer que se exponha uma série de discussões que envolvem tanto considerações pós-colonialistas como pós-estruturalistas. Destarte, este artigo procura mirar-se sobre a teorização produzida a partir do "Terceiro Mundo", de um país (ou um conjunto de países) do Sul global, o que abriria potencial espaço para a interlocução com a produção no campo mainstream do conhecimento político, como também com as várias perspectivas inclusas no que se pode designar como uma "teoria política feminista" ocidental.

Palovras-chave: teoria política feminista; América Latina; perspectiva; Terceiro Mundo.
\end{abstract}

Copyright (๑) 2013 by Revista Estudos Feministas.

$1 \mathrm{MMM}, 2009$.

2 As primeiras experiências de transnacionalização do feminismo ocorreram junto à realização das conferências internacionais sobre as mulheres, sediadas na Cidade do México (1975), Copenhagen (1980), Nairóbi (1985) e Pequim (1995), e outras conferências importantes como a do Rio de Janeiro (1992), Viena (1993) e Cairo (1994), onde foram contempladas discussões e debates, como também a formação de alianças, entre diversos atores organizações internacionais, atores governamentais e não governamentais e entidades da sociedade civil -, para a definição e implementação de uma plataforma de ações indispensáveis para o avanço, empoderamento e efetivação de direitos para as mulheres no mundo. Sonia ALVAREZ, 2003, também chama a atenção para a importância de
"Contra a política neoliberal, são as mulheres da Marcha Mundial" - esse foi um dos lemas do bloco das feministas, que com o seu batuque animou a caminhada pelas ruas do centro de Porto Alegre na passeata de abertura do Fórum Social Mundial, em 2005. Mulheres de diferentes classes, cores, raças, etnias, orientações sexuais, faixas etárias e nacionalidades compuseram esse bloco, demonstrando a ampla variedade de articulações, sejam elas locais, nacionais e/ou internacionais, como ainda a prática e execução das reais possibilidades para a formatação de redes feministas. O exemplo aqui evocado, da Marcha Mundial de Mulheres, esclarece como se pleiteia a legitimidade organizacional de mulheres que se alinham a uma agenda radical anticapitalista e antipatriarcal, fazendo com que uma rede de seis mil grupos de 159 países e territórios faça parte de um movimento global. ${ }^{1}$ A partir de tal evento é possível estabelecer certos padrões do que hoje é conhecido como feminismo transnacional: ${ }^{2}$ um movimento atento às interseções entre nacionalidade, raça, gênero, sexualidade e exploração econômica numa escala mundial, em decorrência principalmente da emergência do capitalismo global; um movimento autointitulado "altermundialista", ${ }^{3}$ por sua luta de cunho internacional 
encontros regionais na formação de redes de militância ocorridos nas décadas de 80 e 90 . Neuma AGUIAR,2009, aponta que as próticas e discursos antes desse eventos eram exclusivamente locais e que, a partir daí, possibilitou-se o acesso e troca de experiências entre diferentes culturas, através especialmente da conformação de redes e de ONGs.

3 "Altermundialista" refere-se ao principal lema dos Fóruns Sociais Mundiais: "Um outro mundo é possível".

${ }^{4}$ Virginia VARGAS, 2003

${ }^{5}$ ALVAREZ, 1990, p. 5, tradução nossa. contra o neoliberalismo e pela busca por justiça social. Porém, alguns desacordos relativos ao possível reducionismo econômico da luta contra a globalização - pensada quase exclusivamente por sua estrutura opressiva econômica capitalista - permearam essas articulações políticas, criando novas demandas por questões relativas ao reconhecimento de diferenças nesses espaços. ${ }^{4}$

A partir dessas novas experiências do ativismo político e social do feminismo discutir-se-á como o redimensionamento da política nos planos nacional e internacional se refletiu na academia latino-americana, gerando preocupações sobre as novas (ou as fragmentadas) fronteiras geográficas que foram refletidas nas atividades de teorização. Deverá ser enfatizado, na discussão que se segue, como os propósitos políticos se sobressaíram num cenário político global permeado por desigualdades, implicando uma busca por teorias da justiça social que deem conta de responder às questões que incitam a discussão sobre estas mesmas desigualdades, sejam elas locais, regionais ou globais. Na América Latina, foi em meio a condições de profunda subordinação patriarcal que o feminismo latino-americano, mesmo que restrito no seu começo, eclodiu através de movimentos de reivindicação e conscientização feminina, seja na forma dos partidos, nas organizações políticas, em periódicos, nos centros de estudo e nas organizações não-governamentais, tentando superar e questionar a condição política, cultural, religiosa e econômica vigente, já que a América Latina seria, segundo Sonia Alvarez, "[...] uma região onde o machismo é sancionado pelo Estado e santificado pela Igreja Católica".5 Desse modo, a movimentação política em torno dos ideais feministas e de gênero possibilitaram a luta por justiça social, como é apresentado por Ana Sampaolesi:

Reivindicar a hierarquia da luta por justiça de gênero implica para o feminismo um desafio, por sua vez, político e teórico. Levaria a nos colocar deliberadamente no campo do político como sujeitos portadores de sentido e criadores de novos significados à concepção geral da justiça social. Ele constitui em si mesmo uma possibilidade a mais de gravitar naqueles aspectos relacionados com os valores, as imagens e crenças que são geradas e consolidadas dentro de uma comunidade. ${ }^{6}$

Assim, este artigo 7 procura emaranhar essas diretivas num projeto crítico que vislumbraria a efetiva consolidação acadêmica e a centralidade teórica que se considera ser devida à perspectiva latino-americana e feminista. Para tanto, caberia elencar, desde já, uma série de perguntas: o que poderia significar um projeto latino-americano de teoria 
${ }^{8}$ Chandra MOHANTY, 1984.

9 Cicero ARAUJO e Javier AMADEO, 2009, p. 11.

${ }^{10}$ ARAUJO E AMADEO, 2009

"ARAUJO e AMADEO, 2009, $\mathrm{p}$ 12.

${ }^{12}$ Alejandra CIRIZA, 2009, p. 244

${ }^{13}$ Marlise MATOS, 2008, 2009a 2009b, 2010. política? A partir do lugar do subalterno - do latino, da mulher, do indígena, do negro, dos cidadãos e cidadãs do considerado "Terceiro Mundo"8 etc. -, o que significaria a construção de um modelo teórico universal? Quais são as contribuições da "teoria política feminista" ocidental para a reflexão sobre a América Latina? O que é o feminismo e a justiça social a partir desse projeto? Ainda não é possível saber se todas essas perguntas poderão ser respondidas, porém, sabe-se que os acadêmicos e teóricos latinoamericanos confrontam-se com uma posição aparentemente paradoxal e rica, já que lhes cabe produzir um saber que esteja localizado entre o local e o global, entre o particular e o universal, e a forma como estes se entrelaçam seria uma grande contribuição para o campo do conhecimento político. ${ }^{9}$

Segundo Cicero Araujo e Javier Amadeo, ${ }^{10}$ houve um considerável aumento do diálogo entre os latino-americanos e a produção acadêmica "ocidental", provocado pelo incremento nas "interações além-fronteira". Porém, como os autores chamam a atenção, "[...] a manutenção de um diálogo rico e frutífero depende da interlocução de locutores dispostos a debater, sem contudo abrir mão de suas experiências". Por isso, o papel dos teóricos e teóricas latinoamericanos seria relativamente instigante: pela necessidade de se teorizar, isto é, descrever, criticar e prescrever sobre a situação e a conjuntura política, eles aprenderam com as teorias universais, mas também passaram a criticá-las e desde então começaram a produzir respostas às suas próprias inquietações. " Somando-se a essas considerações, o ideal feminista no campo do conhecimento pode ser alcançado a partir da atividade de "[...] falar de nós [que] permite apelar a uma idealização mínima para mobilizar as subjetividades individuais em prol de um projeto político antipatriarcal, anticapitalista, um projeto feminista olhando para o sul a partir do sul". ${ }^{12}$

Ainda, pretende-se apresentar um breve mapeamento das discussões centrais e disputadas na teoria política feminista contemporânea, para deter-se numa abordagem aprofundada sobre o período atual, referente à consolidação de um momento em que há a confluência da terceira e quarta ondas, como também da constituição de um terceiro e novo modelo teórico-analítico. De antemão, é crucial apontar a centralidade da noção de gênero, como um conceito mais amplo, que reporia toda a discussão feminista atual e expandiria as fronteiras da categoria "sexo". Por isso, cabe ressaltar a importância da proposta que pretende lançar mão do conceito de campo de gênero e de um modelo teórico que seja desta vez crítico-emancipatório. ${ }^{13}$ Partindo do modelo tridimensional de Nancy Fraser, as discussões que se 


\footnotetext{
14 FRASER, 2009a[2009].

${ }^{15}$ HABERMAS E DERRIDA, 2003.
}

16 YOUNG, 2007, p. 2, tradução nossa.

17 CONWAY e SINGH, 2009.

${ }^{18}$ CONWAY e SINGH, 2009, p. 79, tradução nossa.

19 FRASER, 2009a[2009].

${ }^{20}$ ANZALDÚA, 1987.

${ }^{21}$ ANZALDÚA, 1987, p. 58-59. dão em torno da justiça social problematizarão os dimensionamentos das justiças mas, para além de Fraser, problematizar-se-á a contextualização da autora sobre o feminismo diante do processo de globalização, pois, ao enfatizar o aspecto recente transnacional do movimento feminista, ela recorre simplesmente ao exemplo da Europa ocidental como sendo um caso bem-sucedido. ${ }^{14}$ A autora cairia no mesmo erro de Habermas e Derrida ${ }^{15}$ ao situar esse movimento quase exclusivamente na Europa, já que, segundo Iris Young, "[...] pode ser argumentado que movimentos no sul global teriam liderado a criação de uma esfera pública global". ${ }^{16} \mathrm{E}$, como será demonstrado, os movimentos feministas latino-americanos têm tido um papel protagonista na tessitura e no emaranhamento dessas redes internacionais.

Ainda, para além de Fraser, retomando as críticas de Janet Conway e Jakeet Singh ${ }^{17}$ ao modelo teórico da autora, "[a] 'história' em que Fraser situa sua teoria crítica [é] uma história singular e universal do capitalismo, da modernização e do gradual cumprimento do Liberalismo. [E por causa disto] sua teoria crítica se torna uma teoria universal da democracia e da justiça social". ${ }^{18}$ De fato, ao problematizar o feminismo contemporâneo, Fraser ${ }^{19}$ acaba delimitando-o ao feminismo "universal", "ocidental", que é o feminismo norteamericano e europeu, o que não contribui tanto para uma reflexão latino-americana, nem para uma teoria realmente com alcances universais.

Antes, deve-se resgatar a inspiração de Gloria Anzaldúa ${ }^{20}$ para o feminismo do Sul, o feminismo latinoamericano, na sua condição de dubiedade, de suas inconsequências, buscas, desconstruções e questionamentos ao mainstream do Norte global, ao malestream da teoria vigente, americanismo, branqueamento, ocidentalismo e imperialismo dos feminismos norte-americano e europeu, que revolucionou na década de 80 os estudos feministas e de gênero, tanto na literatura, como na concepção estruturalista/ fronteiriça (na geografia territorial e a dos corpos):

Deslenguadas. Somos los del español deficiente. We are your linguistic nightmare, your linguistic aberration, your linguistic mestisaje, the subject of your burla. Because we speak with tongues of fire we are culturally crucified. Racially, culturally and linguinguistically somos huérfanos - we speak an orphan tongue [...] I will have my serpent's tongue - my woman's voice, my sexual voice, my poet's voice. I will overcome the tradition of silence. ${ }^{21}$

14 Estudos Feministas, Florianópolis, 21(1): 11-39, janeiro-abril/2013 
22 JAQUETTE, 1989, p. 1, tradução nossa.

${ }^{23}$ COSTA, 2000.

\section{Um projeto crítico feminista a partir do Sul}

Discutir sobre um projeto teórico feminista a partir da América Latina requer que se exponha uma série de discussões que envolvem tanto considerações póscolonialistas como pós-estruturalistas. Destarte, mirar-se sobre a teorização produzida a partir do "Terceiro Mundo", de um país (ou um conjunto de países) do Sul global, abriria potencial espaço para a interlocução com a produção no campo mainstream do conhecimento político, como também com as várias perspectivas inclusas no que se pode designar como uma "teoria política feminista" ocidental. Porém, como nos diz Jane Jaquette, a visão do Sul, em especial da América Latina, é marginalizada:

As feministas norte-americanas estão cada vez mais conscientes do trabalho das feministas canadenses e europeias, especialmente escritoras francesas e britânicas, mas elas ainda tendem a ver as mulheres do Terceiro Mundo como vítimas da opressão e não como criadoras da teoria feminista ou como agentes de mudança. ${ }^{22}$

Com isso, Cláudia Lima Costa, ${ }^{23}$ ao expor questionamentos acerca das rotas pelas quais conceitos e teorias do feminismo viajam nas Américas, bem como das formas como estes são traduzidos nesses contextos geográficos e históricos, explora o conceito de "tradução cultural", oriundo dos estudos pós-coloniais e da antropologia para se referir a um processo pelo qual estaria fortemente imbricada uma profunda assimetria de poder entre povos, culturas e linguagens. Desse modo, denunciam-se, por exemplo, as trocas desiguais entre as periferias e centros metropolitanos, já que aos centros caberia a produção teórica e à periferia a atividade restrita de estudos de caso. ${ }^{24}$ Além disso, percebe-se que, cada vez mais, o "tráfego internacional de conceitos" tem enfraquecido substancialmente as relações entre as teorias e os lugares, bem como subvertido a autenticidade e a ordem, já que em consequência dos processos de transnacionalização e transmigração, segundo Cláudia Costa, haveria risco elevado de despolitização dessas teorias e conceitos:

Devido à intensa transmigração dos conceitos e valores nas viagens dos textos e das teorias, frequentemente um conceito com um potencial de ruptura politica e epistemológica e num determinado contexto, quando transladado a outro, despolitiza-se. ${ }^{25}$

O que se quer aqui é emitir um primeiro sinal de alerta: este trabalho de análise e de "tradução" no campo relativo ao conhecimento político é quasi-antropológico, pois retrata 
${ }^{26}$ MOHANTY, 1984, 2003; Homi BHABHA, 1994.

27 Donna HARAWAY, 2008[1988]. ${ }^{28}$ Gayatri SPIVAK, 1985, 1994[1989], 2006[1987].

${ }^{29}$ Adrienne RICH, 1986; MOHANTY, 1998[1992].

30 Joan SCOTT, 1992[1991].

${ }^{31}$ MOHANTY, 1984. a necessidade de se problematizar teoricamente primeiro o devir do produtor do conhecimento para depois o dever ser e o vir a ser das reflexões normativas no campo do conhecimento. Para se evitar as reposições das próprias estruturas de desigualdade, desta feita no âmbito da academia, como uma analogia à distinção freyriana entre a Casa Grande e a Senzala a partir de um renovado fluxo transnacional, é necessário rediscutir as novas cartografias, bem como os redimensionamentos econômicos, políticos, culturais, libidinais, geográficos etc. Para se evitar que a teoria seja somente um signo do Ocidente ${ }^{26} \mathrm{e}$, dessa forma, reestabelecendo aqui 0 vínculo do Ocidente como o opressor colonial, torna-se necessário e urgente que se problematize o posicionamento imperialista nas teorias feministas e no campo do conhecimento político e, para isso, faz-se necessário explorar formas e mecanismos que possibilitem o "conhecimento situado", ${ }^{27}$ a "possibilidade de um subalterno falar", ${ }^{28}$ as "políticas de interpretação" ${ }^{29} \mathrm{e}$ a própria ênfase na "experiência", ${ }^{30}$ ainda que nem todas as teóricas feministas aqui apresentadas e que tratem dessa discussão tenham origem nos países do Sul.

Em primeiro lugar destaca-se que, invariavelmente, colonização é um conceito que tem sido utilizado para referir-se a uma dominação estrutural que, reconhece-se, suprimiria a heterogeneidade dos sujeitos em questão. Segundo Mohanty, ${ }^{31}$ haveria três variações relevantes deste conceito: i) a marxista, que denuncia a exploração econômica; ii) a discussão realizada pelas feministas negras, que denunciam a forma pela qual suas experiências e lutas foram apropriadas pelos movimentos de mulheres brancas; e iii) as reivindicações do "Terceiro Mundo", que buscam caracterizar e questionar o que é evidenciado na produção de um discurso cultural ocidental e colonialista sobre o que é chamado "Terceiro Mundo": principalmente, as hierarquias políticas e econômicas.

Diante disso, o foco da análise de Chandra Mohanty é o que ficou conhecido e delimitado "sob os olhos do Ocidente" como uma específica interpretação do que seja a "mulher do Terceiro Mundo", especialmente na produção ocidental - norte-americana e europeia - feminista. Assim, procurou-se evidenciar quais seriam os tipos de apropriação e de codificação do conhecimento sobre a "mulher do Terceiro Mundo" produzidas e articuladas pelos Estados Unidos e pela Europa Ocidental. Em sua análise, então, Mohanty expõe a diferenciação entre os conceitos "mulher" e "mulheres": o primeiro relativo ao "outro" ideológico e cultural, que seria construído discursivamente, enquanto o segundo conceito referir-se-ia aos sujeitos reais. A partir disso, argumenta a autora, uma análise pós-colonial feminista deveria denunciar

16 Estudos Feministas, Florianópolis, 21 (1): 11-39, janeiro-abri//2013 
32 HARAWAY, 2008[1988].

33 HARAWAY, 2008[1988], p. 346, tradução nossa.

${ }^{34}$ SPIVAK, 1994[1989], p. 198.

${ }^{35}$ SPIVAK, 2006[1987].

${ }^{36} \mathrm{RICH}, 1986$. e desconstruir o que foi constituído a partir da noção de "mulher do Terceiro Mundo", já que as feministas ocidentais denuncia e critica a autora -, arbitrariamente, as "colonizaram", negando-lhes a efetiva heterogeneidade e materialidade, bem como, erroneamente, assumiram através das agendas do movimento um discurso universalista que supostamente incluiria "todas as mulheres". Esse tipo de procedimento, recorrente no feminismo acadêmico ocidental, homogeneíza e sistematiza/banaliza também a opressão das mulheres.

É certo que em todos os conhecimentos e em suas expressões científicas nenhuma perspectiva de dentro é privilegiada, já que, de acordo com Haraway, ${ }^{32}$ haveria na dinâmica "dentro e fora de fronteiras" do conhecimento teorizações feitas de acordo com os respectivos fluxos de poder. Isso quer dizer que, no "jogo do conhecimento", a poderosa arte da retórica é imprescindível para uma disputa, já que "[...] todo conhecimento é uma conexão condensada em um campo de poder agonístico [...]". ${ }^{33}$ Logo, a partir dessas perspectivas, os conhecimentos "situados" e "corporificados" deveriam ser retratados diante das diversas formas de conhecimento não situados e, consequentemente, irresponsáveis.

Contra essas formas claras de colonização e de produção de um tipo de conhecimento irresponsável, Gayatri Spivak nos apresenta outra estratégia:

[...] falar "de dentro" das narrativas emancipatórias dominantes, mesmo quando se distanciar destas. Ela deve se negar resolutamente a oferecer fantasmáticas contranarrativas nativistas hegemônicas, que implicitamente respeitam o regulamento histórico de quem tem "permissão para narrar". ${ }^{34}$

Como, para a autora, a relação entre teoria e representação é sempre conturbada, constata-se que nenhuma teoria realmente representa, já que ela não poderia falar pelos grupos subalternos. ${ }^{35} \mathrm{~A}$ saída para os grupos oprimidos e subalternos seria, então, conquistar o poder cultural ou étnico por meio da reivindicação do conhecimento, incidindo em críticas à cultura política dominante e buscando refazer completamente as relações de poder - e não repô-las ao conquistar poder. A "possibilidade de um subalterno falar" se referiria à possibilidade dada a uma complexa situação política e estratégica numa dada sociedade.

Se falar a partir de uma posição ou perspectiva é uma situação política e estratégica, então, deve-se somar ainda a ideia de "política da localização" proposta por Adrienne Rich, ${ }^{36}$ que ressalta o aspecto da localização da autora/autor, da sua participação em algum mainstream, 
${ }^{37}$ MOHANTY, 1998[1992].

${ }^{38}$ MOHANTY, 1998[1992], p. 269, tradução nossa.

${ }^{39}$ SCOIT, 1992[1991].

${ }^{40}$ Diana MAFFIA, 2004, p. 173 tradução nossa. localizando-se no ato de teorizar, identificando quais seriam os seus próprios pontos de partida no "aqui" e no "agora". De forma muito similar, Mohanty ${ }^{37}$ se propõe a problematizar a "política da experiência", já que, segundo ela, os textos feministas devem ter e valorizar a autoconsciência da sua própria produção em relação às noções de "experiência" e "diferença". A experiência, entendida como uma noção que pode rearticular a prática política e de conhecimento feminista na produção de diferentes referências e significados, define-se como um método "[...] que deve ser historicamente interpretado e teorizado se é para se tornar a base para a solidariedade e luta feminista e seria, neste momento, que uma compreensão da política da localização prova ser crucial". ${ }^{38}$

A partir da "multiplicação dos sujeitos do conhecimento", a ortodoxia do saber passou a ser confrontada pela legitimação e autorização da experiência - principalmente a experiência direta dos "Outros". De tal forma, Joan Scott ${ }^{39}$ informa como a evidência da experiência torna-se central para a construção de uma noção de múltiplos sujeitos, pois, desestabilizando as premissas ideológicas e as categorias de representação, perceber-se-ia a existência do "outro", possibilitando a discussão acerca de sua construção. Seria importante notar que os indivíduos não têm experiência; quem a têm são os sujeitos que são construídos por e através delas. Logo, a evidência da experiência possibilitaria explicar a própria produção do conhecimento através da prática de interpretação. No caso da América Latina, seria crucial lançar mão da evidência e interpretação da experiência para incluir numa análise uma série de eventos e situações vivenciados pelos seus cidadãos e cidadãs,:

Na América Latina deveríamos agregar ditaduras, desaparecidos, paramilitares, guerrilhas, genocídios, fome, desemprego, desesperança. E as mulheres deveriam agregar ainda a feminização da pobreza, violência, abortos clandestinos, violações, prostituição e assassinatos impunes. ${ }^{40}$

As perspectivas e as condições da subalternidade latino-americana, através da busca por teorizar a "experiência", o "conhecimento situado" e a "localização", como também ao questionarem estruturas e conceitos previamente e "racionalmente" definidos por um projeto moderno ocidental, no entendimento e interpretação aqui defendidos, buscariam se articular hoje como projetos epistemológicos alternativos, repensando (e negando algumas vezes) o diálogo com o Norte global e recuperando ou criando novos e outros diálogos a partir do Sul global. A proposta de uma "epistemologia do Sul" feita por Boaventura

18 Estudos Feministas, Florianópolis, 21 (1): 11-39, janeiro-abril/2013 
${ }^{41}$ SANTOS, 2008.

${ }^{42}$ MATOS, 2008.

${ }^{43}$ MATOS, 2008, p. 352, itálicos da autora.

${ }^{44}$ MATOS, 2010.

${ }^{45}$ MATOS, 2010, p. 10. de Souza Santos ${ }^{41}$ procura repensar o conhecimento produzido pelo Norte e traduzido pelo Sul através da "experiência do contato" - que é uma experiência de limites e fronteiras. Então, rever a tradução e a "representação" do Norte significaria produzir conhecimentos próprios e diferentes daqueles que foram fornecidos pelo mainstream ocidental, moderno, cartesiano etc.

Enfim, resgatando todos os possíveis instrumentais epistêmicos supracitados, poder-se-ia dizer que o papel ativo do feminismo na construção de espaços de interlocução acadêmica acabou por instituir um novo campo do conhecimento, enraizado na experiência latino-americana, no Brasil principalmente, que tem como carro-chefe o próprio pensamento feminista: o campo de gênero..$^{42}$ Ao discutir esse conceito e a dinâmica desse campo, Marlise Matos coloca que,

Numa proposta de conhecimento, de ciência em que o que se valoriza é o modo de pensar e as suas consequências e não a descrição do mundo, que não vê o conhecimento como uma representação neutra do mundo ontológico externo, é que poderia estar inserida a proposta de ação de um novo campo de gênero e feminista. Ou seja: sabendo e reconhecendo que o conhecimento (científico) é capaz de intervir e agir sobre o mundo, que ele possui consequências sobre o mundo, que ele é ação sobre o mundo, é que proponho a sustentação teórica, epistemológica e política do campo de gênero e feminista como sendo da ordem de um universal histórico e contingente que opera dinâmica e paradoxalmente na busca constante e responsável de um devir gênero que por sua vez se desdobra na afirmação radicalizada de um devir ciência. ${ }^{43}$

Procura-se, portanto, chamar a atenção para a atividade de teorização que se atrelaria à produção de um conhecimento propriamente latino-americano. O papel do feminismo aqui é protagonista na medida em que se vislumbra a necessidade de reposição de cânones e tradições ocidentais. Segundo a mesma autora, ${ }^{44}$ esse papel dar-se-ia através de uma "epistemologia da transgressão emancipatória", pois, "[...] ainda que sem um ponto de chegada definitivo, ressalto a necessidade do mesmo ponto de partida: a clarificação normativa e crítico-reflexiva em relação aos próprios pressupostos históricos, aqueles da cultura da qual se fala, da qual se enuncia e se interpela". ${ }^{45}$ Por sua vez, as metas e objetivos desse projeto seriam cumpridos através da seguinte dinâmica exposta pela autora: 
${ }^{46}$ MATOS, 2010, p. 10.

47 Donna Maureen CHOVANEC, 2000

${ }^{48}$ Céli Regina PINTO, 1994, p. 196.
Assim todas as regras passam a estar constantemente em estado de suspeição e questionamento com vistas à produção da justiça e da emancipação sociais, já que neste mundo interconectado globalmente, visceralmente habitado por multiculturas que já perderam em definitivo a condição de inocência antevista na possibilidade de isolamento, tudo aquilo que concernir ao conhecimento e ao direito, por exemplo, das mulheres e dos gêneros, estará permanentemente aberto ao debate público e internacional (e, desta forma, contra todos os pressupostos e justificações fundamentalistas, sejam estes de quais estatutos forem). ${ }^{46}$

A partir disso, pensar do ponto de vista e da perspectiva da América Latina em um projeto teórico político feminista e de gênero conforma-se com a necessidade de se formatar uma outra "teoria política feminista" (que ainda permanece entre aspas), visto que a experiência vivida pelo movimento feminista latino-americano reflete-se em um processo complexo de interseções que se deu a partir de um conjunto diferenciado de opressões, pois combina o colonialismo francês, espanhol e português, com os governos ditatoriais e populistas, com dinâmicas específicas da globalização econômica, cultural e política. A América Latina seria um dos lugares de nosso planeta, bem como a Ásia e a África, onde as desigualdades se manifestam de modo muito acirrado e específico, por isso a indiscutível necessidade de novas teorias e enquadramentos que falem, a partir de uma dimensão totalmente localizada, da justiça social uma importante demanda coletiva. ${ }^{47}$ Dessa forma, problematizar "o" político e "a" política a partir deste continente pode ser retraçado a partir da própria experiência dos movimentos feministas e de mulheres, quando estes travam seus frequentes embates contra o Estado e também quando começam a lutar e disputar pela presença na esfera política, pois este foi um lugar onde as mulheres estavam forjadas na militância

[...] de movimentos clandestinos, torturadas sexualmente nas prisões da ditadura; na luta pela anistia; nos movimentos contra a violência do estado contra o corpo da mulher, principalmente da mulher pobre esterilizada pela democracia; contra a pobreza; a favor da mulher sem terra. ${ }^{48}$

\section{De acordo com Jane Jaquette,}

Essas experiências ofereceram à teoria feminista latinoamericana um ponto de vantagem único para se analisar os limites entre público e privado, para debater como os grupos de mulheres podem "fazer política" no intuito de provocar uma mudança social no 
${ }^{49}$ JAQUETTE, 1989, p. 6, tradução nossa.

50 SANTOS, 2008, p. 16.

${ }^{51}$ SANTOS, 2008, p. 14.
52 JAQUETTE, 1989: ALVAREZ, 2000[1998]; Sueli CARNEIRO, 2006.

${ }^{53}$ ALVAREZ, 2000[1998], p. 386. contexto democrático e para reestruturar as imagens políticas e mesmo a própria linguagem da política. ${ }^{49}$

Repensar a dinâmica que envolve as lutas por justiça social requer que se rediscuta a agenda feminista nos processos de (re)democratização. Diante disso, confluindo a práxis com uma "epistemologia feminista do Sul", visa-se, pois, estimular a aposta na possibilidade de se construir uma "nova cultura política" baseada, conforme define Santos, numa "racionalidade mais ampla e mais cosmopolita que a racionalidade moderna ocidental"; 50 ou mesmo uma nova cultura política que "[...] permita voltar a pensar e a querer a transformação social e emancipatória, ou seja, o conjunto dos processos econômicos, sociais, políticos e culturais que tenham por objetivo transformar as relações de poder desigual em relações de autoridade partilhada". ${ }^{51}$ Estaria na base dessa reconstrução política a retomada radicalizada da própria democracia, onde gênero e feminismo assumem, através das contribuições do feminismo acadêmico contemporâneo, uma perspectiva singular; pois sua reconstrução e ressignificação poderiam fomentar o reconstruir mais original dessas novas bases para uma outra forma de interação democrática - um outro devir democracia, na constante busca por concepções ônticas e ontológicas do que é "a" política e "o" político.

\section{A próxis e a noção do que é "a" política e "o" político a partir do Sul}

Para discutir a questão relativa à experiência do movimento feminista latino-americano e como os conceitos foram sendo (re)pensados, caberia apresentar aqui algumas dos passos históricos que confluíram para essa construção, resgatando as principais ondas do movimento feminista na América Latina. O intuito é o de apontar a disputa entre feministas "políticas" e "autônomas" e, por último, apresentar os novos desafios colocados diante da globalização e da transnacionalização do feminismo, a partir das contribuições deste continente. Toma-se aqui, principalmente, o feminismo brasileiro como base e referência para algumas das discussões sobre "a" política e "o" político, como também a sua própria história, pois, segundo entende parte significativa da literatura que trata desse percurso, este seria o movimento mais bem-sucedido da América Latina. ${ }^{52}$

O feminismo deve ser entendido "[...] como um campo de ação expansivo, policêntrico e heterogêneo que abarca uma vasta variedade de arenas culturais, sociais e políticas". ${ }^{53}$

Ademais, é importante lembrar que o ativismo feminista conflui com a "redescoberta do político" pelos movimentos 
${ }^{54}$ A atuação de movimento e a formatação de agendas dos movimentos feministas são compreendidas por algumas autoras a partir de duas fases (ou ondas) distintas, como nos diz Susan Besse 1999[1996]: a primeira "onda" é relativa ao feminismo sufragista $e$ "bem comportado", na qual os esforços feministas questionavam a legislação até então vigente e buscavam a inserção da mulher na política e, com isso, a efetivação da cidadania feminina; e a segunda "onda", conhecida pelo feminismo radical, compreende os movimentos nas décadas de 70 e 80 , quando se retomam as críticas ainda não realizadas pela primeira onda, incorporando ao discurso do movimento demandas vinculadas ao quadro geral da opressão sofrida pelas mulheres e o reconhecimento das diferenças sexuais na cena pública. A segunda onda centrou sua luta em assuntos de particular interesse das mulheres, como a violência doméstica, as creches, os direitos sexuais e os direitos reprodutivos (ALVAREZ 2000[1998]). Em confluência com a segunda onda, a inserção das mulheres no âmbito da masculina academia, assim como a emergência da teoria feminista nesse espaco, retomou os pontos centrais da agenda do ativismo feminista que denunciava a opressão das mulheres. Acrescentam-se ainda às duas ondas uma fase de tentativas de reforma nas instituições democráticas, no próprio Estado, como também a busca pela reformatação dos espaços públicos, pela qual se sobressaem as divergências intragêneros - o que é nomeado de "feminismo difuso" por Céli PINTO, 2003 além da proposta de uma fase mais recente, "quarta onda" (MATOS, 2010; Solange SIMÕES e Marlise MATOS, 2008), na qual o movimento consegue se institucionalizar, adentrando os espaços estatais e garantindo a formulação de políticas públicas com o enfoque de gênero.

${ }^{55}$ AGUIAR, 2009, s/n.

56 Verônica SCHILD, 2000[1998].

57 ALVAREZ, 2000[1998]. sociais através de uma esfera própria potencialmente pluralista que, por sua vez, reavalia e procura repor a democracia liberal. As diferentes formas de Estados, compreendidos como um conjunto de instituições políticas e práticas com consequências poderosas, induzem diferentes significados na vida dos cidadãos e cidadãs, isto é, a América Latina, especialmente a partir de seus Estados autoritários e de seus Estados dependentes, o que produziu reações no âmbito da sociedade civil distintas de outros países que possuíam/em Estados previdenciários, democráticos ou de bem-estar.

Ao se analisarem as "ondas" do feminismo na América Latina procurou-se demonstrar as distintas formas de ação e as diferenciadas dinâmicas desse movimento e de suas agendas (e não seria somente uma questão de agenda já que se entende ela própria como sendo bastante fluida). ${ }^{54}$ No decorrer dessas ondas, pôde-se constatar que, definitivamente, o feminismo se pluralizou, abrindo espaço para a atuação em diversos âmbitos: militantes partidárias, mulheres negras, intelectuais, militares clandestinas, "mães", líderes de movimentos populares, diretoras e servidoras de órgãos governamentais, até teólogas. De acordo com Neuma Aguiar, a experiência que tem sido vivenciada pelo feminismo, pelo menos nas últimas duas décadas, o nutre com o "[...] contato internacional e intercâmbio [pois oferece] a oportunidade de acesso a diferentes formas de comportamento que são distintos daqueles determinados no âmbito da própria cultura", além do que também "[...] objetivam alcançar uma série de objetivos feministas, em lugar de buscar atingir um único propósito". ${ }^{55}$ As redes feministas aqui então configuradas envolvem o trabalho de organizações não-governamentais e de base, bem como estão engajadas na produção do conhecimento. ${ }^{56}$ Segundo Alvarez, ${ }^{57}$ os processos de Beijing (1995) fizeram com que se deflagrasse no continente: i) a circulação dos discursos feministas e a multiplicação dos espaços e lugares de atuação; ii) a absorção de elementos das agendas e discursos feministas por algumas instituições culturais dominantes, organizações paralelas da sociedade civil, política e Estado, além do establishment internacional do desenvolvimento; iii) a ONGuização, especialização e profissionalização de alguns setores do movimento; iv) a articulação e formação de redes; e v) a transnacionalização dos discursos e práticas do movimento feminista.

Vinculando-se um conjunto de questões conceituais é possível perceber que, a cada onda, emergiria um conflito ao se abordar "a" política: negando-a por ser "essencialmente" masculina ou, ao contrário, aceitando-a como um espaço para ser efetivamente explorado e transformado. Há 
${ }^{58}$ ALVAREZ, 2000[1998], p. 387.

59 HEILBORN e ARRUDA, 1995, $\mathrm{p}$ 20.

${ }^{60}$ ALVAREZ, 2000[1998].

${ }^{61}$ MATOS, 2010.

${ }^{62}$ ALVAREZ, 2000[1998], p. 416.

${ }^{63}$ LAMAS, 2000 também a necessidade de menção às diferenças existentes entre as feministas que acreditam que a luta das mulheres deve ser travada dentro do Estado e dos partidos - aquelas consideradas políticas ou "independentes" - e aquelas que acreditam na autonomia e que a luta deva se deter exclusivamente no âmbito do movimento - as "autônomas". De forma geral, a "[...] maioria deu as costas para o Estado e evitou a arena política convencional - considerada então (com razão) excludente, opressiva, inimiga de todas as reivindicações de justiça social, sem falar da justiça de gênero". ${ }^{58}$ Por outro lado, importa destacar que o discurso relativo à necessidade de se adentrar os espaços formais da política (os "espaços de poder") poderia possibilitar uma prática feminista mais integrada, já que as feministas impactariam e transformariam, de dentro, os discursos e as práticas político-culturais dominantes. Esse embate remetenos a duas concepções possíveis sobre "o" político discutidas nos capítulos anteriores: aquele relativo à política cultural retratada em íntima relação com os movimentos sociais; e o político com feições schmittianas, representado por um antagonismo entre inimigos, como parece estar colocado o debate que envolve a relação entre as feministas autônomas e o Estado.

O projeto de um "feminismo horizontal" - que se caracteriza para Maria Luiza Heilborn e Ângela Arruda ${ }^{59}$ na descentralização e autonomia da cultura feminista diante de outras agências, implodindo as hierarquias existentes dentro do próprio movimento, valorizando a participação direta, o "não-monopólio da palavra, ou informação", enfim, se horizontalizando de forma complacente aos princípios de organização própria da democracia radical - foi, aos poucos, sendo substituído pela especialização e profissionalização, o que Alvare ${ }^{60}$ chama de "ONGuização", já que haveria uma dificuldade do feminismo horizontal em realizar as tarefas de produção de conhecimento especializado. Por isso, pode-se notar, ao passo de uma nova onda, ${ }^{61}$ que

A ONGuização e transnacionalização do campo feminista latino-americano levou um número crescente de feministas a privilegiar alguns espaços da política feminista, tais como o Estado e as arenas políticas internacionais, em relação aos esforços de transformar as representações predominantes de gênero, enfatizar as mudanças de consciência e promover a transformação cultural por meio de atividades de organização e mobilização das bases locais. ${ }^{62}$

A dinâmica atual do movimento feminista, então, poderia ser traduzida em três formas de presença com êxito em distintas áreas, como Marta Lamas ${ }^{63}$ apresenta: i) a 
${ }^{64}$ MATOS, 2010.

${ }^{65}$ LAMAS, 2000, p. 5, tradução nossa.

${ }^{66}$ SCHILD, 2000[1998], p. 168.

${ }^{67}$ SCHILD, 2000[1998], p. 170.

${ }^{68}$ ALVAREZ, 2000[1998], p. 416.

${ }^{69}$ LAMAS, 2000. profissionalização do movimento, especializando-se em áreas temáticas, oferecendo suporte para as demandas políticas (principalmente políticas públicas); ii) a legitimação, tanto acadêmica como política, da perspectiva de gênero, adentrando em espaços acadêmicos; e iii) a consolidação do discurso sobre a mulher no âmbito público. De tal forma, a quarta "onda", que estaria sendo vivenciada atualmente pelos movimentos feministas na América Latina (principalmente os brasileiros), orientar-se-ia, segundo Matos, ${ }^{64}$ para a conformação de "circuitos de difusão feminista" que têm sido operados a partir de distintas correntes horizontais do feminismo, as quais se orientariam em direção às diversas arenas paralelas de atuação dos movimentos no âmbito da sociedade civil, como também a partir das fronteiras existentes entre a sociedade civil e o Estado. Esse momento é, sem dúvida, aquele para o qual Marta Lamas chama a atenção: "[...] muitas feministas já funcionam mais a partir de realidades políticas do que de posturas ideologizadas: assumem a dimensão pragmática da intervenção política e começam a manifestar paixão por negociar conflitos". ${ }^{65}$

Ainda que as conquistas proporcionadas por essas transformações internas sejam louváveis, algumas contendas tendem ainda a permanecer, visto que, segundo Verônica Schild, "[...] a integração política de algumas mulheres está se fazendo às custas da marginalização de outras. As lutas pela articulação dos direitos das mulheres dentro do Estado envolvem as mulheres de modo diferente [...]". ${ }^{66}$ Dessa forma, quais seriam as saídas possíveis para tais problemas - "Quem tem o direito de definir os termos das lutas das mulheres?". ${ }^{67}$ Uma saída possível seria democratizar as relações de dentro do movimento, visto que,

Embora as muitas mulheres diferentes que transitam dentro do campo latino-americano ainda 'se reconheçam' mutuamente como tal - mesmo quando põem em questão a 'legitimidade ontológica' da 'outra' -, estão se forjando novas hierarquias e relações de poder dentro desse campo vasto e complexo e os parâmetros de legitimidade, interlocução, responsabilidade e representação são continuamente renegociados e contestados. ${ }^{68}$

Em geral, poder-se-ia dizer, de acordo com Marta Lamas $^{69}$ - que estabelece como parâmetro de suas considerações as experiências no âmbito do feminismo mexicano -, que a dimensão conceitual sobre o político, ou estaria ligada à concepção de que tudo é político estando, assim, vinculada ao exercício do poder -, ou vinculada estreitamente à ideia de negociação e gestão. Ao associar-se o poder político com uma ideia da política

24 Estudos Feministas, Florianópolis, 21(1): 11-39, janeiro-abril/2013 
70 LAMAS, 2000 , p. 5-7

${ }^{71}$ Hannah ARENDT, 2007b [195-?]

72 LAMAS, 2000, p. 7, tradução nossa.

${ }^{73}$ MATOS, 2010, p. 19. entendida em seu modo tradicional, ligada ao privilégio masculino, algumas ativistas rejeitaram ou desprezaram as atividades desenvolvidas nos espaços de gestão ou de negociação política. E, mesmo ao assumir uma concepção totalizante em que o "pessoal é político", a corrente "autônoma" do feminismo resistiu em se inserir na dinâmica política nacional. Na medida em que foi sendo aceita a diferença sexual no trabalho político das organizações, o movimento percebeu que o seu avanço também passaria por uma participação maior nas instâncias governamentais e partidárias. ${ }^{70}$ Além do mais, nos palcos supranacionais (encontros, conferências, fóruns), a política foi sendo descaracterizada como "dominação masculina", e passou-se a compreendê-la "como liberdade", ${ }^{71}$ ou, a partir da chave em uma grande aposta: a de se pensar a política como tradução. O que se quer enfatizar é que é perceptível a passagem da afirmação de um modo antagonístico para referir-se ao político para o seu entendimento e interpretação a partir de novas formas de se pensar, agora agonisticamente, as lutas entre amigos. Segundo Lamas,

[...] este passo, de uma visão da política como prática masculina, a uma reivindicação da política como algo próprio e necessário, marca o processo de alguns grupos feministas que expressam uma crescente profissionalização da intervenção feminista na vida pública e corresponde a uma transformação no imaginário político. ${ }^{72}$

Permanece, então, a aposta: é a "[...] primeira vez que se faz possível e até palpável vislumbrar e reconhecer a ideia do fluxo, do trânsito movimentalista. Quem sabe com esse outro inovador dinamismo não seja concretizável o sonho da superação das injustiças que ainda corroem nosso mundo". ${ }^{73}$ Nesse sentido, a percepção da realidade das diversas interseções do movimento feminista latino-americano com a política direcionaria a procura por modelos mais complexos e que realmente contemplem essas necessidades e práticas.

\section{O feminismo latino-americano e as teorias da justiça: a partir e para além de Nancy Fraser}

A aproximação dos feminismos latino-americanos, principalmente o acadêmico, refletidos na prática da tradução, implicou concepções equivocadas de tradução sobre as lutas políticas por justiça a partir das próprias experiências feminista latino-americanas. Segundo Pedro José Di Pietro, ${ }^{74}$ deve-se chamar a atenção para os limites 
${ }^{75}$ Segundo DI PIETRO, 2006, p. 200, tradução nossa, "[...] as teorizações de Nancy Fraser em torno da justiça de gênero e a justiça social tornaram-se a moeda corrente nos centros acadêmicos/ políticos da América Latina que se ocupam principalmente de problemáticas ligadas ao Gênero e a análises de suas relações. Pelo menos na Argentina, país em que Fraser visitou mais de um par de vezes, seus artigos e posições alcançaram não somente notoriedade mas também um valor simbólico que coloca como percurso necessário nos Estudos de Gênero".

76 PINTO, 2002.

77 PINTO, 2002, p. 88.

${ }^{78}$ PINTO, 2002, p. 94-96.

79 FRASER, 2001[1997]. da "incorporação" de uma teoria política que busque respostas para questões específicas de certos países (em geral, os Estados Unidos e países da Europa Ocidental). Nesse sentido, haveria necessidade de se superar as dificuldades de trânsito comumente experimentadas nos limites e fronteiras geopolíticas e históricas. As contribuições teóricas de Nancy Fraser para uma discussão teórica especificamente latino-americana são claras, ${ }^{75}$ porém muitos pontos não se encaixam à prática política vivenciada pelos distintos feminismos da região.

Preocupada com a relação entre a democracia brasileira e as desigualdades sociais, Céli Pinto, ${ }^{76}$ por sua vez, se debruça sobre a discussão da teoria política feminista para apontar possíveis elementos teóricos que colaborem para um melhor entendimento dessa problemática. De acordo com a autora, a contribuição teórica de Nancy Fraser reuniria elementos que seriam efetivamente fundamentais para se pensar a realidade brasileira, quais sejam: i) a noção de públicos e contra-públicos alternativos; e ii) a afirmação normativa do paradigma da justiça social operando a partir da chave redistribuição-reconhecimento. Ainda que Pinto reconheça que "[0] argumento de Fraser é bastante economicista, pouco admitindo a possibilidade de uma transformação nas bases econômicas da injustiça a partir de uma intervenção política", ${ }^{77}$ as conclusões de Pinto são favoráveis ao modelo de Fraser para a compreensão de dimensões específicas envolvidas no "pensar" e no "agir" sobre a questão brasileira.

Desse modo, Pinto ${ }^{78}$ aponta que as relações entre as contribuições teóricas de Fraser e a realidade brasileira seriam as seguintes: i) ainda que Fraser $^{79}$ tenha certas dúvidas quanto à efetividade das políticas de redistribuição afirmativa, no Brasil são elas que têm tido, ao menos por enquanto, os resultados mais positivos; ii) mesmo com a pluralização dos contra-públicos alternativos, no Brasil eles não conseguiram alcançar aqueles resultados efetivamente positivos no sentido da modificação estrutural das condições de pobreza; iii) os contra-públicos alternativos, por outro lado, desafiam a noção estática de uma sociedade organizada e, no caso da complexa sociedade brasileira, permite, a partir de seu interior, evidenciar a pulverização de potencialidades organizativas; e iv) para avançar na questão sobre as desigualdades sociais, a existência de um público forte representacional que é o parlamento, com múltiplos outros públicos fortes participativos, também com poder de decisão, permitiria reflexões sobre os possíveis instrumentos democráticos capazes de colaborar na construção de uma saída para os problema graves das desigualdades sociais do país. 
${ }^{80}$ DI PIETRO, 2006.

81 DI PIETRO, 2006, p. 183 , tradução nossa.

82 VARGAS, 2003, 2008

${ }^{83}$ FRASER, 2001[1997].
Já para Di Pietro, ${ }^{80}$ mesmo que Fraser procure no conceito de paridade participativa", por um lado, satisfazer a necessidade de se lidar com conflitos e diferenças intra e inter-públicos, por outro, a sua abrangência conceitual reduziria a existência das perspectivas sociais, das intenções, como também das práticas públicas por adotar uma noção restrita de "público". Outra crítica do autor endereçada a Fraser se baseia nos pressupostos da realidade comunicacional como propostos pela autora, já que estes não seriam explicativos o suficiente para se compreender a fundo todas as vertentes do poder que o atravessam. Dessa forma, a interpretação do horizonte de protestos pelo Movimento LGTBI na Argentina demonstraria que o modelo teórico de Nancy Fraser desvaloriza uma importante dimensão da prática e da efervescência dos discursos e sugestões que se apresentam como públicos e que redefiniriam, por sua vez, os limites e o significado de público. O modelo da autora também seria limitado por não perceber que as diferenças identitárias e entre os grupos sociais nem sempre são inevitáveis nem irreconciliáveis, o que debilita a possibilidade da afirmação de uma possível veia emancipatória que estaria contida na ideia de "contra-públicos" - "[...] se é que esta se entende no marco da necessidade de fazer espaço para múltiplas vozes e intervenções e inclusão de múltiplos projetos dentro de uma ou diferenciadas esferas de ação e comunicação". ${ }^{81}$

Virgínia Vargas ${ }^{82}$ procurou retraduzir $\circ$ paradigma bidimensional da justiça de Nancy Fraser ${ }^{83}$ numa discussão que contemple a experiência feminista nos atuais processos de transnacionalização. A autora também utiliza a categoria "redistribuição" para referir-se às demandas contra o neoliberalismo, o foco de intensa disputa nas articulações feministas, como é o caso das organizações deste teor no âmbito do Fórum Social Mundial (que para algumas feministas seriam um "terreno disputado"). Ela também insiste que, algumas vezes, a categoria do reconhecimento fica obscurecida. Então, acompanhando Fraser, a autora reforça que, dentro desse cenário transnacional, dois tipos de luta contra a injustiça seriam relevantes: i) aquelas lutas contra injustiças relativas ao impacto socioeconômico que estariam enraizadas nas estruturas políticas e econômicas; e ii) aquelas vinculadas aos valores culturais e econômicos que estariam enraizadas nos padrões sociais de representação e comunicação. Para a autora, poderiam ser percebidos reflexos extensivos sobre a macroeconomia, sobre os macroprocessos políiticos e sobre o processo de globalização em si, sendo esses reflexos acompanhados por intervenções feministas que se pautam em formas peculiares e criativas de interação do global com o local, como por exemplo seria o caso da Marcha Mundial das Mulheres. 
${ }^{84}$ VARGAS, 2003.

${ }^{85}$ CONWAY e SINGH, 2009.

${ }^{86}$ FRASER, 2003.

87FRASER, 2008.

${ }^{88}$ Para outras críticas ao monismo normativo ver Axel HONNETH, 2009, e Marlise MATOS, 2009a. ${ }^{89}$ FRASER, 2009a[2009].
A emergência de um espaço transnacional onde a possibilidade de suscitar novas questões, de elaborar novas estratégias de como se aproximar de novas realidades, possibilitando, assim, a construção de uma nova e outra cultura política, mais democrática e inclusiva, poderia ser conferida nos encontros promovidos nos Fóruns Sociais Mundiais. Sustentando os lemas "um outro mundo é possível" e "não aos pensamentos únicos", para Vargas, ${ }^{84}$ nesses espaços e através da luta contra o neoliberalismo e o capitalismo global é que teria se tornado possível e permitido às feministas a construção de novas abordagens e alianças, como também o repensar das conceituações de autonomia para o movimento. Porém, Vargas também reconhece que haveria uma concepção ainda limitada de Fraser ao se utilizar do paradigma bidimensional, quando esta mesma percebe e ressalta a articulação dos movimentos feministas como fortemente atuantes nessas redes, especialmente no sentido de demandar mais lugar e mais espaços de poder. A discussão sobre "os pensamentos únicos" chegou a ser problematizada por Vargas, mas, no entanto, não chegou a ser contraposta à ideia do monismo normativo, com a "paridade de participação" proposta por Fraser.

Em Conway e Singh ${ }^{85}$ há a problematização do monismo normativo, a proposta contida na "paridade da participação", sugerido por Fraser, ${ }^{86}$ como também há a denúncia de que a própria compreensão da autora sobre o Fórum Social Mundial (pensado através de um enquadramento da teoria democrática liberal) não notaria e/ou levaria a sério muitos dos seus aspectos mais interessantes e inovadores. ${ }^{87}$ A própria experiência dos Fóruns, tendo como evidentes os compromissos com a diversidade e o pluralismo, opondo-se sem nenhuma dúvida a qualquer proposta de pensamento único, contradiz a ideia de um monismo normativo, já que numa teoria assim estruturada não haveria espaço, então, para a afirmação, por sua vez, de um pluralismo normativo. Pelos Fóruns e pelo movimento transnacional feminista concluiu-se que nenhum monismo normativo, ou qualquer forma de pensamento único, seria possível (ou desejável) para uma política global que se sustente como radical. ${ }^{88}$

Em artigo mais recente surgem novos problemas na base teórica formulada por essa autora. ${ }^{89}$ Desta vez, os problemas seriam relativos à dinâmica e etapas do movimento feminista, já que se evidencia que Fraser, através de um reducionismo na sua discussão, restringindo-se a teorizar sobre o movimento a partir de um olhar estritamente do movimento feminista norte-americano, mais uma vez, opera suas considerações através de um enquadramento liberal e capitalista como eixos estruturadores da dinâmica 
${ }^{90}$ Caberia ressaltar que esse artigo evidenciaria uma possível crise do feminismo norte-americano.

91 FRASER, 2009a[2009]. do feminismo na contemporaneidade. ${ }^{90}$ Segundo Fraser, ${ }^{91}$ a agenda do movimento feminista deslizaria sobre o eixo histórico do capitalismo estatal (state-organized capitalism) para um capitalismo transnacional, pós-fordista e neoliberal (ver Quadro 1).

QUADRO 1 - Dinâmica da segunda onda do feminismo nos Estados Unidos segundo FRASER, 2009a[2009]

\begin{tabular}{|c|c|c|}
\hline $\begin{array}{c}\text { Feminismo e o capitalismo } \\
\text { estatal }\end{array}$ & $\begin{array}{l}\text { Feminismo e o "novo } \\
\text { espírito do capitalismo" }\end{array}$ & $\begin{array}{l}\text { Feminismo e o pós- } \\
\text { neoliberalismo }\end{array}$ \\
\hline $\begin{array}{l}\text { Feminismo contra o econo- } \\
\text { micismo } \\
\text { O feminismo buscou repor uma } \\
\text { visão monista e economicista da } \\
\text { justiça por uma visão ampliada, } \\
\text { tridimensional, que compreendia } \\
\text { economia, cultura e política. }\end{array}$ & $\begin{array}{l}\text { Feminismo } \\
\text { antieconomicismo } \\
\text { ressignificado } \\
\text { As reivindicações feministas por } \\
\text { justi-ça foram cada vez mais } \\
\text { elaboradas como reivindicações } \\
\text { de reconheci-mento da } \\
\text { identidade e da diferença. }\end{array}$ & $\begin{array}{l}\text { Feminismo pós-neoliberal } \\
\text { antieconomicismo } \\
\text { Adotar uma visão completa da } \\
\text { tridimensionalidade da justiça, que } \\
\text { possivelmente contrabalance } \\
\text { melhor as dimensões do } \\
\text { reconhecimento, da redistribuição } \\
\text { e da representação. }\end{array}$ \\
\hline $\begin{array}{c}\text { Feminismo contra o andro- } \\
\text { centrismo } \\
\text { Luta para incorporar a justiça de } \\
\text { gênero no capitalismo estatal, } \\
\text { como também incluir as questões } \\
\text { sobre as mulheres na própria } \\
\text { esquerda radical. }\end{array}$ & $\begin{array}{l}\text { Feminismo antiandrocen- } \\
\text { trismo ressignificado } \\
\text { O capitalismo desorganizado } \\
\text { incorpora o discurso do avanço das } \\
\text { mulheres e da justiça de gênero, } \\
\text { ao mesmo tempo incorporando } \\
\text { um discurso sobre a valorização do } \\
\text { trabalho assalariado. }\end{array}$ & $\begin{array}{l}\text { Feminismo pós-neoliberal } \\
\text { antiandrocentrismo } \\
\text { O feminismo deve militar para } \\
\text { formas de vida que descentre o } \\
\text { trabalho assalariado e valorize } \\
\text { atividades não-assalariados, como } \\
\text { o cuidado da casa. }\end{array}$ \\
\hline $\begin{array}{l}\text { Feminismo contra o } \\
\text { estatismo } \\
\text { Rejeição ao ethos burocrático- } \\
\text { administrativo do capitalismo } \\
\text { estatal. }\end{array}$ & $\begin{array}{l}\text { Feminisnmo antiestatismo } \\
\text { A perspetiva feminista que } \\
\text { procurava transformar o poder } \\
\text { estatal em meio para empodera- } \\
\text { mento e justiça social passa a ser } \\
\text { utilizada como discurso para } \\
\text { legitimar a mercantilização e para } \\
\text { a limitação do Estado. }\end{array}$ & $\begin{array}{c}\text { Pós-neoliberal antiestatismo } \\
\text { Busca por uma democracia } \\
\text { partici-pativa, militando por uma } \\
\text { nova forma de organização do } \\
\text { poder político, que subordine a } \\
\text { burocracia ao empoderamento } \\
\text { dos cidadãos e cidadãs. Fortalecer } \\
\text { o poder público. }\end{array}$ \\
\hline $\begin{array}{c}\text { Feminismo contra e a favor } \\
\text { do westfalianismo } \\
\text { Por um lado, o movimento estava } \\
\text { sensível às injustiças } \\
\text { transfronteiriças, principalmente as } \\
\text { feministas envolvidas com o } \\
\text { "mundo em desenvolvimento". Por } \\
\text { outro lado, a maioria das } \\
\text { feministas via no seu respectivo } \\
\text { Estado o lugar de demandas para } \\
\text { seus interesses próprios. }\end{array}$ & $\begin{array}{c}\text { Feminismo contra e a favor } \\
\text { do westfalianismo } \\
\text { ressignificado } \\
\text { A globalização permitiu novas } \\
\text { formas de ativismo feminista } \\
\text { (transnacional, multiescalar), } \\
\text { porém com algumas dificuldades, } \\
\text { já que o que era uma tentativa } \\
\text { para ampliar o alcance da justiça } \\
\text { além do Estado-nação acabou } \\
\text { por se integrar em alguns } \\
\text { aspectos com as necessidades } \\
\text { administrativas de uma nova } \\
\text { forma de capitalismo. }\end{array}$ & $\begin{array}{c}\text { Pós-neoliberal anti- } \\
\text { westfalianismo } \\
\text { ância por uma nova ordem } \\
\text { política pós-vestifaliana que seja } \\
\text { multies-calar e democrática a } \\
\text { cada nível. }\end{array}$ \\
\hline
\end{tabular}

Fonte: elaborações próprias a partir de FRASER, 2009a[2009]. 
92 PINTO, 2003

${ }_{93}$ MATOS, 2010.

${ }^{94}$ Segundo Emir SADER, 2009, a América Latina emergiu-se como - lugar onde é possível se contestar a "reinante" política neoliberal. No Brasil, a eleição de Lula seria um indício para uma virada pós-neoliberal.
A partir dessas considerações recentes da autora, podese dizer que o enquadramento que ela propõe não seria traduzível ou sequer transportável para o contexto da América Latina, ou mesmo para toda a experiência feminista do Sul global, ainda que ela reconheça o papel dos Fóruns Sociais Mundiais. Fraser reduz todo o período da década de 70 até os dias atuais em uma única onda (segunda onda), onde haveria uma agenda e um discurso que confluiriam com as demandas por redistribuição, reconhecimento e representação num primeiro momento, e num segundo momento haveria a conformação de um backlash, onde toda a agenda atual, a partir da fragmentação do discurso feminista, seria utilizada e ressignificada por estratégias vinculadas ao discurso neoliberal.

Conforme apresentado, está claro que as vicissitudes do feminismo latino-americano não podem ser reduzidas ao enquadramento norte-americano proposto por Fraser. Isso porque ele não foi ou estaria sendo utilizado por inteiro pelo neoliberalismo, pois a força do Sul global no contexto recente do planeta surge justamente a partir daí, na negação e na reação ao neoliberalismo. Parte do feminismo latinoamericano pode até ter sido "vítima" desse efeito perverso, porém outra parte, igualmente significativa, tem contribuído para o desmascaramento do discurso generificado do neoliberalismo, mostrando também aos feminismos do Norte o rumo equivocado em que estes se encontravam.

Assim, pensando agora a partir da experiência latinoamericana e brasileira e de uma outra forma as etapas dinâmicas do movimento feminista, pensando-as numa proposta diferenciada à de Fraser, poder-se-ia dizer que a dinâmica capitalista conformar-se-ia com as "ondas" já anteriormente descritas. Dessa forma, sinalizaria que a segunda onda estaria localizada no âmbito daquilo que Fraser define como capitalismo estatal; a onda subsequente e relativa ao período neoliberal referir-se-ia ao momento de ONGuização e da constituição de um "feminismo difuso", ${ }^{92}$ sendo a quarta onda, conforme proposto por Matos, ${ }^{93}$ aquela vinculada ao que Fraser designa por período pós-neoliberal - um "futuro aberto" para Fraser. Acredita-se e está se procurando dar destaque neste artigo, então, que o futuro, o destino, da dinâmica feminista norte-americana seria, curiosamente, o vivido e o presente atuais da América Latina e do Brasil, já que, a partir do governo Lula, o Brasil (bem) aos poucos vem reestruturando e construindo a desafiante proposta de um Estado pósneoliberal, ${ }^{94}$ que contém na dimensão da inclusão democrática de parte significativa dos movimentos sociais (ainda que alguns movimentos ainda se mantenham "autônomos") um eixo norteador e emblemático.

Mesmo com o avanço propiciado por Fraser, que desenvolveu a proposta de um modelo tridimensional para a 
${ }^{95}$ MATOS, 2009a.

96 SCHUTTE, 2000.

justiça social, ainda se faz necessário uma aposta em progressos teóricos ainda mais significativos. Entende-se que seria necessário ir adiante, explicitando, principalmente, os aspectos subentendidos, aqueles que não foram ainda explicitados e tratados justamente devido a formatos e organizações epistemológicas reducionistas que não os incluem em suas teorizações - aqueles elementos de inclusão democrática que são tão característicos quando se trata da experiência e da prática dos feminismos latino-americanos. Por isso, a proposta de uma teoria crítico-emancipatória feminista e de gênero, avançada por Matos $^{95}$ à luz de uma profunda crítica epistêmica, propõe um conjunto de rearranjados elementos que seriam considerados absolutamente cruciais quando se pretende a construção de uma forma de teorização que esteja além dos paradigmas dialéticos e binarizantes, bem como daqueles que podem ser, de modo muito fácil, culturalmente reduzidos (principalmente aos contornos dos modelos do Ocidente, nesse caso). Essa proposta avança na direção de se pensar os eixos estruturadores da justiça social numa dimensão significativamente mais ampliada, inclusive numa perspectivação analítica que dê destaque e singularidade à dimensão paradoxal e simultânea de repor as dimensões da igualdade e da diferença na complexidade, propondo realocar uma das principais contendas no feminismo latinoamericano (e também nos feminismos em outras regiões) que seria, segundo Ofelia Schutte, ${ }^{96}$ o debate entre as feministas igualitárias e os feminismos da diferença.

Pensar a partir das referências teóricas e epistemológicas da contingência e dos paradoxos (premissas relevantes, como visto, a algumas vertentes da recente teoria política feminista) parece uma contribuição significativa para se fazer avançar as teorias da justiça social e também as teorias democráticas contemporâneas. Sabe-se que as organizações políticas se constituem mediante exclusões. Num sentido até mesmo psicanalítico, o inevitável retorno daquilo que foi excluído é, justamente, o que está a forçar a expansão e a rearticulação das premissas básicas da democracia. A história da formação de uma organização política democrática, nesse sentido, precisa estar sempre aberta - um devir democracia - pois é/está inexoravelmente incompleta. Mesmo o projeto hegemônico democrático - entenda-se: as democracias representativas liberais e ocidentais - são projetos inacabados e incompletos. Isso não significa dizer que sejam de todo equivocadas. Trata-se de uma incompletude constitutiva na qual todos os seus sujeitos estão igualmente incompletos, exatamente porque estão se constituindo nesse processo, ou seja, através de exclusões que se tornam (por meio de lutas contingentes) politicamente salientes e não 
${ }_{97}$ MATOS E CYPRIANO, 2008, p. 78.

${ }^{98}$ ARENDT, 2007b[195-?].

${ }_{99}$ ARENDT, 2007b[195-?], p. 39. porque sejam estaticamente estruturais ou fundacionais. É "[...] pensar simultaneamente [...] num movimento claramente pós-socialista e pós-dialético, a rede de multiplicidades de agenciamentos que condicionam e ao mesmo tempo que libertam, a nossa realidade paradoxal". 97

Ao se pensar na necessidade de incluir a representação política como mais uma dimensão da justiça, algo que este artigo perseguiu, simplesmente viu-se emergir mais uma versão pós-estruturalista de universalidade/universal: desta vez intencionalmente incapaz de oferecer uma descrição firme, seja substantiva, seja processual, daquilo que seria comum a todos os cidadãos - mulheres e homens, negros e brancos, homo e heterossexuais etc. - enquanto tais no âmbito da representação política. A proposta do universal contingente se articula às formas de estabelecimento prático, praxiológico, pragmático das recentes discussões a respeito da democracia contemporânea: na deliberação negociada entre distintos atores, por sua vez orientada primordialmente para aquilo que consensualmente se constitui (contingentemente) como interesse público. Não se trata da defesa de um universal transcultural pura e simplesmente (já que este também estará manchado pelas normas culturais que tentou transcender); trata-se de uma universalidade que necessita constantemente de ser traduzida, retrabalhada, reposta de modo relacional e político.

O que se propôs como "devir democrático", na modelagem aqui descrita, tem seu ponto de ancoragem nessa possibilidade aberta de novas articulações e formações políticas. Concorda-se e converge-se também para este tipo de abordagem que resgata $a$ indissociabilidade entre justiça e democracia, entre "o" político e "a" política. Tratase sim, em certa medida, da afirmação de uma politização de vastas áreas da vida social (aquilo que teve como efeito abrir caminho para a proliferação de identidades tidas como "particularistas"). O universal contingente conforme esta proposta se articularia então com o devir democracia na medida em que se constata que tais "particularismos" impõem reclamos igualmente universais para os sujeitos e estes seriam, pois, pré-requisitos para a política num sentido pleno: aquela que se estabelece no formato exato como afirmava Hannah Arendt, ${ }^{98}$ que pensava os corpos políticos como formas de participação ativa na pluralidade. Segundo a autora, "[...] a política organiza, de antemão, as diversidades absolutas de acordo com uma igualdade relativa e em contrapartida às diferenças relativas". 99

De maneira geral, poderia ser dito que o reflexo da prática do ativismo político feminista deveria ser e estar projetado num modelo teórico político que, inclusive, seja capaz de repor a luta por justiça social conjugada com as 
100 KIRKWOOD, 1985, p. 66, tradução nossa.

${ }^{101}$ KIRKWOOD, 1985. Segundo Céli Pinto, o desafio colocado ao feminismo brasileiro seria abandonar o excessivo "discurso por direitos" para adentrar num discurso sobre o poder (informação verbal coletada na palestra de abertura do III Seminário Internacional Política e Feminismo, realizado em Belo Horizonte, no dia 15 de outubro de 2009). 102 KIRKWOOD, 1985, p. 67, tradução nossa.

${ }^{103}$ MENDOZA, 2009, s/n.

104 COSTA, 2000.

${ }^{105}$ María Luisa FEMENIAS, 2007.

106 VARGAS, 2003, 2008

107 MATOS, 2009a, 2010.

108 FRASER, 2001[1997], 2005.

109 FEMENIAS, 2007, p. 24 tradução nossa, itálicos da autora. práticas e instituições democráticas. Essa necessidade partiria de um "querer-saber" que, segundo a socióloga chilena Julieta Kirkwood, "[...] surge quando se constata a não correspondência entre os 'valores' postulados pelo sistema e as experiências concretas reais humanas". ${ }^{100}$ Sem o desejo pelo conhecimento sobre "a" política e "o" político, ao feminismo restaria, ou aceitar que as mulheres não lutariam e depreciariam o poder, ou, então, lutar especificamente por direitos. ${ }^{101}$ Para Kirkwood, não haveria um "[...] modelo alternativo válido para desafiar o paradigma patriarcal, o conhecimento que temos vestido e adornado", 102 porém, a partir do papel político do ativismo feminista e entendendo que a teoria antecederia e procederia a ação, para Breny Mendoza,

Como toda construção teórica inserida dentro da lógica da colonialidade do poder, o eurocentrismo e - masculinismo, a construção de uma nova teoria feminista latino-americana passa primeiro por uma desconstrução da teoria feminista ocidental, que até agora tem assentado as pautas do pensamento feminista latino-americano, e, logo se reconstruir como uma teoria feminista descolonial e pós-ocidental pautada desta vez por seu próprio contexto geopolítico-cultural. ${ }^{103}$

Ao se tratar neste artigo de um "tráfego" e "tráfico" de teorias, ${ }^{104}$ pôde-se notar que um vínculo foi estabelecido entre as teorias e os subalternos, produzindo por consequência "lugares de apropriação", ${ }^{105}$ que levam ao fraturamento dos discursos hegemônicos do conhecimento político e da própria "teoria política feminista" ocidental. A proposta de modelos teóricos políticos feministas, como Vargas ${ }^{106}$ e Matos, ${ }^{107}$ que deem conta da multidimensionalidade dos problemas relativos às questões de gênero e feministas na contemporaneidade transpõem o modelo de Nancy Fraser ${ }^{108}$ e também confirmam a ideia de María Luisa Femenias de que "[o] feminismo latino-americano tem algo a dizer e o faz em voz própria". ${ }^{109}$ Isso ratificaria que a partir e para além do lugar das fronteiras, ou dos "territórios-limite", há que se problematizar os modelos de conhecimento apresentados e apostar na elaboração de novas abordagens sobre o que ainda não é e também sobre o que ainda se irá descobrir e problematizar, ou seja, os "territórios selvagens" - redescobrindo e problematizando a partir de nossa América Latina.

\section{Referências}

AGUIAR, Neuma. "Movimentos feministas em perspectiva comparada: América Latina, África e Ásia". In: MATOS, Marlise (Org.). Debates acerca do feminismo: antigos e novos desafios. Belo Horizonte: DCP/FAFICH/UFMG, 2009. 
(Coleção Enfoques feministas e os desafios contemporâneos, v. 1).

ALVAREZ, Sonia E. Engendering Democracy in Brazil: Women's Movements in Transition Politics. Princeton: Princeton University Press, 1990.

. 'A 'globalização' dos feminismos latino-americanos: tendências dos anos 90 e desafios para o novo milênio". In: ALVAREZ, S. E.; DAGNINO, E.; ESCOBAR, A. (Orgs.). Cultura e política nos movimentos sociais latino-americanos: novas leituras. Belo Horizonte: Editora UFMG, 2000. p. 383426 [versão original: "Latin American Feminisms 'Go Global': Trends of the 1990s and Challenges for the New Millennium". In: ALVAREZ, S. E., DAGNINO, E., and ESCOBAR, A. (eds.). Cultures of Politics/Politics of Cultures: ReVisioning Latin American Social Movements. Boulder: Westview Press, 1998. p. 293-324].

. "Um outro mundo (também feminista...) é possível: construindo espaços transnacionais e alternativas globais a partir dos movimentos". Revista Estudos Feministas, v. 11, n. 2, p. 533-540, 2003.

ANZALDUA, Gloria. Bordelands/La Frontera. San Francisco: Aunt Lute, 1987.

ARENDT, Hannah. "Introdução: o sentido da política". In: ARENDT, H.; LUDZ, U. (Orgs.). O que é política? Tradução de Reinaldo Guarany. 7. ed. Rio de Janeiro: Bertrand Brasil, 2007b. p. 124-134;201-202 [versão original: Einführung in die politik. In: LC - cont. 67. 10 pages typed. 195-?].

ARAUJO, Cicero; AMADEO, Javier. "Introdução". In: ARAUJO, C.; AMADEO, J. (Orgs.). Teoria política latino-americana. São Paulo: Hucitec, 2009. p. 11-19.

BESSE, Susan. "Feminismos e (anti)feminismos no Brasil". In: BESSE, S. Modernizando a desigualdade: reestruturação da ideologia de gênero no Brasil, 1914-1940. São Paulo: Edusp, 1999. p. 182-220. [versão original: "The Politics of Feminism(s) and Anti Feminism(s)". In: BESSE, S. Restructuring Patriarchy: The Modernization of Gender Inequalities in Brazil, 1914-1940. Chapel Hill: The University of North Carolina Press, 1996. p. 164-198].

BHABHA, Homi. The Location of Culture. New York: Routledge, 1994.

BRANDÃO, Gildo Marçal. "Teoria política e institucionalização acadêmica". In: QUIRINO, C. G.; VOUGA, C.; BRANDÃO, G. M. (Orgs.). Clássicos do pensamento político. 2. ed. São Paulo: Edusp, 2004 [versão original: "A teoria política é possível?". Revista Brasileira de Ciências Sociais, v. 36, 1998, p. 158-161].

CARNEIRO, Sueli. "Mulheres em movimento". In: PORTO, M. (Org.). Olhares femininos, mulheres brasileiras. Rio de Janeiro: X Brasil, 2006. p. 109-126.

34 Estudos Feministas, Florianópolis, 21(1): 11-39, janeiro-abril/2013 
CHOVANEC, Donna Maureen. "Latin America Feminism". In: CODE, L. (ed.). Encyclopedia of feminist theories. New York: Routledge, 2000. p. 289-291.

CIRIZA, Alejandra. "Corpo e política: sobre 'cidadanias globais' e 'sujeitos nômades'”. In: ARAUJO, C.; AMADEO, J. (Orgs.). Teoria política latino-americana. São Paulo: Hucitec, 2009. p. 227-246.

CONWAY, Janet; SINGH, Jakeet. "Is the World Social Forum a Transnational Public Sphere?: Nancy Fraser, Critical Theory and the Containment of Radical Possibility". Theory, Culture \& Society, v. 26, n. 5, p. 61-84, 2009.

COSTA, Cláudia Lima. "As teorias feministas nas Américas e a política transnacional da tradução". Revista Estudos Feministas, v. 8, n. 2, p. 43-49, 2000.

DI PIETRO, Pedro José J. "¿Adonde van? itinerarios contrapublicos y recorridos plurilogicos". Cuadernos FHyCS-UNJu, n. 31, p. 173-207, 2006.

FEMENIAS, María Luisa. "Esbozo de un feminismo latinoamericano". Revista Estudos Feministas, v. 15, n. 1, p. 11-25, 2007.

FRASER, Nancy. "Da redistribuição ao reconhecimento? Dilemas da justiça na era pós-socialista". Tradução de Márcia Prates. In: SOUZA, J. (Org.). Democracia hoje: novos desafios para a teoria democrática contemporânea. Brasília: Editora UnB, 2001. p. 245-282 [versão original: "From Redistribution to Recognition? Dilemmas of Justice in a 'Postsocialist' Age". New Left Review, n. 1, v. 212, p. 68-93, 1997].

"Políticas feministas na era do reconhecimento: uma abordagem bidimensional da justiça de gênero". In: BRUSCHINI, C.; UNBEHAUM, S. (Orgs.). Gênero, democracia e sociedade brasileira. São Paulo: Editora 34, 2002. p. 61-78.

"Social Justice in the Age of Identity Politics: Redistribution, Recognition and Participation". In: FRASER, N., and HONNETH, A. Redistribution or Recognition? A Political-Philosophical Exchange. London: Verso, 2003. p. 7-109. 2005.

Reframing Justice. Amsterdam: Royal Van Gorcum,

Scales of Justice: Reimagining Political Space in a Globalizing World (New Directions in Critical Theory). New York: Columbia University Press, 2008.

"O feminismo, o capitalismo e a astúcia da história". Tradução de Anselmo da Costa Filho e Sávio Cavalcante. Mediações: Revista de Ciências Sociais, Londrina, v. 14, n. 2, p. 11-33, 2009a [versão original: "Feminism, Capitalism and the Cunning of History". New Left Review n. 56, p. 97-117, 2009]. 
HABERMAS, Jürgen; DERRIDA, Jacques. "February 15, or What Binds Europeans Together: A Plea for a Common Foreign Policy, Beginning in the Core of Europe". Constellations, v. 10, n. 3, p. 291-297, 2003.

HARAWAY, Donna. "Situated Knowledges: The Science Question in Feminism and the Privilege of Partial Perspectives". In: JAGGAR, A. M. (ed.). Just Methods: An Interdisciplinary Feminist Reader. Boulder and London: Paradigm Publishers, 2008. p. 346-352 [versão original: "Situated Knowledges: the Science Question in Feminism and the Privilege of Partial Perspective". Feminist Studies, v. 14, n. 3, 1988, p. 575-599].

HEILBORN, Maria Luiza; ARRUDA, Ângela. "Legado feminista e ONGs de mulheres: notas preliminares". Cadernos ABONG, São Paulo, p. 11-15, 1997.

HONNETH, Axel. "The Fabric of Justice: On the Limits of Proceduralism". FOURTH SYMPOSIUM ON JUSTICE, 4., 2009, Porto Alegre. Papers Fourth Symposium on Justice. Porto Alegre: PUCRS, 2009.

JAQUETTE, Jane S. "Introduction". In: JAQUETTE, J. S. (ed.). The Women's Movement in Latina America: Feminism and the Transition to Democracy. Boston: Unwin Hyman, 1989. p. 1-17.

KIRKWOOD, Julieta. "Feministas y políticas". Nueva Sociedad, n. 78, p. 62-70, 1985.

LAMAS, Marta. • gDe la indentidad a la ciudadanía $\bullet$ h. Cinta de Moebio, Santiago, n.7, p. 1-7, 2000.

MAFFIA, Diana. Socialismo y liberalismo en la teoría política contemporánea. In: BORON, A. (Comp.). Filosofía política contemporánea. Buenos Aires: Consejo Latinoamericano de Ciencias Sociales, 2004. p. 173-177.

MATOS, Marlise. Teorias de gênero ou teorias e gênero? Se e como os estudos de gênero se transformaram em um campo analítico novo para as Ciências Humanas e Sociais. Revista Estudos Feministas, v. 16, n. 2, p. 333-357, 2008.

Em busca de uma teoria crítico-emancipatória feminista de gênero: reflexões a partir da experiência da política na ausência das mulheres. In: MATOS, Marlise (Org.). Perspectiva de gênero na política e nas políticas. Belo Horizonte: DCP/ FAFICH/UFMG, 2009a. (Coleção Enfoques feministas e os desafios contemporâneos, v. 4).

. Uma contribuição para sistematizar aspectos da teoria política feminista e de gênero no Brasil: reflexões a partir da experiência da política na ausência das mulheres. 2009b. Projeto (Bolsa de Produtividade em Pesquisa) Conselho Nacional de Desenvolvimento Científico e Tecnologia, Brasília, 2009b.

O feminismo em sua quarta onda: nova dinâmica de reconfiguração complexa do campo feminista de 
gênero proposta pelos feminismos horizontais latinoamericanos. 2010. Mimeo.

MATOS, Marlise; CYPRIANO, Breno. Críticas feministas, epistemologia e as teorias da justiça social: em busca de uma teoria crítico-emancipatória de gênero. ENCONTRO ANUAL DA ASSOCIAÇÃO NACIONAL DE PÓS-GRADUAÇÃO E PESQUISA EM CIÊNCIAS SOCIAIS, 32., 2008, Caxambu. Anais eletrônicos do XXXII Encontro Anual da Associação Nacional de Pós-Graduação e Pesquisa em Ciências Sociais. São Paulo: Anpocs, 2008.

MENDOZA, Breny. Hacia una nueva teoría feminista latinoamericana (a partir del golpe de estado en Honduras). Disponível em: <http://hondurasenlucha.blogspot.com/ 2009/1 1/hacia-una-nueva-teoria-feminista.html>. Acesso em: $21 \mathrm{dez} .2009$.

MMM - MARCHA MUNDIAL DE MULHERES. Memória. Disponível em: <http: www.sof.org.br/marcha > . Acesso em: 25 nov. 2009.

MOHANTY, Chandra Talpade. "Under Western Eyes: Feminist Scholarship and Colonial Discourses". boundary 2, v. 12, n. 3, p. 333-358, 1984.

"Feminist Encounters: Locating the Politics of Experience". In: PHILLIPS, A. (ed.). Feminism and Politics. Oxford and New York: Oxford University Press, 1998. p. 254-272 [versão original: "Feminist Encounters: Locating the Politics of Experience". In: BARRETT, M., and PHILLIPS, A. (eds.). Destabilizing Theory. Cambridge: Polity Press, 1992].

Feminism without borders: decolonizing theory, practicing solidarity. Durhan and London: Duke University Press, 2003.

PINTO, Céli Regina Jardim. "Movimentos sociais: espaços privilegiados da mulher enquanto sujeito político". In: COSTA, A.; BRUSCHINI, C. (Orgs.). Uma questão de gênero. Rio de Janeiro e São Paulo: Rosa dos Tempos e Fundação Carlos Chagas, 1992. p. 127-150.

"Participação (representação?) política da mulher no Brasil: limites e perspectivas". In: SAFFIOTI, H.; MUÑOZVARGAS, M. (Orgs.). Mulher brasileira é assim. Rio de Janeiro: Rosa dos Tempos, 1994.

"Teoria política feminista, desigualdade social e democracia no Brasil”. In: BRUSCHINI, C.; UNBEHAUM, S. (Orgs.). Gênero, democracia e sociedade brasileira. São Paulo: Editora 34, 2002. p. 79-96.

. Uma história do feminismo no Brasil. São Paulo: Editora Fundação Perseu Abramo, 2003.

$\mathrm{RICH}$, Adrienne. "Notes Toward a Politics of Location". In: RICH, A. Blood, Bread and Poetry: Selected Prose 1979-1985. New York: W.W. Norton and Company, 1986. p. 210-231.

SADER, Emir. A nova toupeira: os caminhos da esquerda latino-americana. São Paulo: Boitempo, 2009. 
SAMPAOLESI, Ana. "La justicia social y las mujere"s. Feminaria, ano V, n. 8, p. 13-14, 1992.

SANTOS, Boaventura de Sousa. A gramática do tempo: para uma nova cultura política. São Paulo: Editora Cortez, 2008.

SCHILD, Verônica. "Novos sujeitos de direitos? Os movimentos de mulheres e a construção da cidadania nas novas democracias". In: ALVAREZ, S.; DAGNINO, E.; ESCOBAR, A. (Orgs.). Cultura e política nos movimentos sociais latinoamericanos: novas leituras. Belo Horizonte: Editora UFMG, 2000. p. 149-183 [versão original: "New Subjects of Rights? Women's Movements and the Construction of Citizenship in the 'New Democracies'". In: ALVAREZ, S. E., DAGNINO, E., and ESCOBAR, A. (eds.). Cultures of Politics/Politics of Cultures: Re-Visioning Latin American Social Movements. Boulder: Westview Press, 1998. p. 93-117].

SCHUTTE, Ofelia. "Latin America". In: JAGGAR, A. M., and YOUNG, I. M. (eds.). A Companion to Feminist Philosophy. Malden, MA: Blackwell Publishers, 2000. p. 87-95.

SCOT, Joan W. "Experience". In: BUTLER, J. P., and SCOT, J. W. (eds.). Feminists Theorize the Political. New York: Routledge, 1992. p. 22-40 [versão original: "The Evidence of Experience". Critical Inquiry, v. 17, n. 4, p. 773-797, 1991].

SIMÕES, Solange, and MATOS, Marlise. "Modern Ideas, Traditional Behaviors, and the Persistence of Gender Inequality in Brazil". International Journal of Sociology, v. 38, n. 4, p. 94-110, 2008.

SPIVAK, Gayatri C. "Can the Subaltern Speak?: Speculations on Widow Sacrifice". Wedge, v. 7, n. 8, p. 120-130, 1985. . "Quem reivindica a alteridade?". Tradução de Patrícia Farias. In: HOLLANDA, H. B. (Org.). Tendências e impasses: o feminismo como crítica da cultura. Rio de Janeiro: Rocco, 1994. p. 187-205 [versão original: "Who Claims Alterity?". In: KRUGER, B., and MARINAI, P. (eds.). Remaking History. Seattle: Bay Press, 1989. p. 269-292].

"A Literary Representation of the Subaltern: A Woman's Text from Third World". In: SPIVAK, G. In Other Worlds: Essays in Cultural Politics. 2nd. ed. New York: Routledge, 2006[1987]. p. 332-370.

VARGAS, Virginia. "Feminism, Globalization and the Global Justice and Solidarity Movement". Cultural Studies, v. 17, n. 6, p. 905-920, 2003.

Feminismos en América Latina: su aporte a la política y a la democracia. Lima: Fondo Editorial de la Facultad de Ciencias Sociales, 2008.

YOUNG, Iris Marion. Global Challenges: War, Self Determination and Responsibility for Justice. Cambridge: Polity, 2007. 
[Recebido em setembro de 2011 , reapresentado em março de 2012 e aceito para publicação em maio de 2012]

Constructing a Latin American Feminist Political Thinking: Focusing on Politics, Social Justice and the "Third World Woman"

Abstract: Discussing a feminist theoretical project from Latin America requires exposing a series of debates which involves considerations from both post-colonial and post-structuralist theories. Thus, this article aims at focusing on the theory generated from the "third world", from a country (or a set of countries) of the global South, which would open a potential space for dialogue within the production in the mainstream of political knowledge, as well as with the several perspectives ded in what we can call Western "feminist political theory".

Key Words: Feminist Political Theory; Latin America; Perspective; Third World. 